\title{
Does Hook Choice Matter? Effects of Three Circle Hook Models on Postrelease Survival of White Marlin
}

\author{
John E. Graves* and AndriJ Z. Horodysky \\ Virginia Institute of Marine Science, College of William and Mary, Post Office Box 1346, \\ Gloucester Point, Virginia 23062, USA
}

\begin{abstract}
Throughout the Atlantic, the white marlin Kajika albida (formerly Tetrapturus albidus) is overfished but remains a major target species for offshore recreational anglers. The vast majority of white marlin taken in the U.S. fishery are caught on natural baits and subsequently released. A previous study demonstrated that the use of circle hooks with natural baits resulted in a highly significant increase in white marlin postrelease survival relative to the use of straight-shank (J-type) hooks with natural baits. However, several models of circle hooks, which vary in shape and the degree to which the point is offset from the shaft, are available to anglers. Survival estimates determined from experiments conducted using one model may not be transferable to other models. We evaluated postrelease survival of white marlin caught on three circle hook models commonly used in the recreational fishery. High-resolution pop-up satellite archival tags that were programmed to release from the fish after $10 \mathrm{~d}$ were deployed to follow the fates of 20 white marlin caught on each type of circle hook. Only one mortality was inferred from the 59 tags that provided useful data. No significant differences in the incidence of deep (internal) hooking, hook-induced trauma, or postrelease survival were found among fish caught on the different circle hook models. Incidences of white marlin deep hooking, hook-induced trauma, and postrelease mortality were significantly lower for the three circle hook models (combined) than for $\mathbf{J}$ hooks evaluated in a previous study. Current U.S. domestic management measures requiring the use of non-offset circle hooks with natural baits during registered tournaments for Atlantic billfishes (Istiophoridae) will provide some relief for white marlin; however, the use of circle hooks in recreational fisheries targeting this species throughout the Atlantic Ocean could substantially reduce fishing mortality on this overfished resource.
\end{abstract}

The U.S. Atlantic offshore recreational fishery interacts with a multispecies assemblage of epipelagic fishes that includes several istiophorid billfishes, swordfish Xiphias gladius, a variety of tunas Thunnus spp. and smaller scombrids, and the dolphinfish Coryphaena hippurus. The white marlin Kajika albida (revised from Tetrapturus albidus) by Collette et al. [2006]) is an important component of this assemblage and is targeted by several tournaments along the U.S. mid-Atlantic coast. The apparent abundance of white marlin has been greatly reduced over the past 50 years. At the most recent full stock assessment of white marlin in 2002, the Standing Committee for Research and Statistics (SCRS) of the International Commission for the Conservation of Atlantic Tunas (ICCAT) estimated that the Atlantic stock is overfished and that overfishing is occurring (ICCAT 2003). Several simulations undertaken by the SCRS during the assessment resulted in estimates of current biomass that were less than $20 \%$ of that necessary for maximum sustainable yield. In response to declining stock abundance, the U.S. National Marine Fisheries Service

\footnotetext{
* Corresponding author: graves@vims.edu
}

Received June 22, 2007; accepted July 26, 2007

Published online March 31, 2008
(NMFS) was petitioned in 2001 to list white marlin as threatened or endangered under the U.S. Endangered Species Act. Although NMFS concluded that there was not sufficient evidence to list white marlin as threatened or endangered at that time, it was noted by the White Marlin Status Review Team (2002) that international cooperation would be necessary to significantly reduce fishing mortality on this overfished species.

White marlin occur as an incidental bycatch species in commercial fisheries and are targeted by directed recreational fisheries throughout their range in the Atlantic Ocean. The majority of fishing mortality in Atlantic white marlin results from the pelagic longline fishery for tunas and swordfish (ICCAT 2001). In an effort to reduce fishing mortality on white marlin by the pelagic longline fishery and maintain current effort for target species whose stocks were in better condition, ICCAT adopted a binding management measure in 2000 requiring the release of all white marlin and blue marlin Makaira nigricans that are alive at the time of pelagic longline gear retrieval (haulback; ICCAT Recommendation 00-13). For almost 20 years, U.S. domestic regulations have prohibited pelagic longline fishermen from possessing Atlantic istiophorid billfishes, regardless of disposition. Logbook records 
and data from the U.S. observer program indicate that the majority of white marlin are alive at the time of haulback (Cramer 2000), and a recent study demonstrated that most white marlin released alive from pelagic longline gear survive (Kerstetter and Graves 2006).

The magnitude of Atlantic-wide recreational fishing mortality in white marlin is considerably smaller than that of the pelagic longline fishery, but it is by no means negligible (ICCAT 2001). In the USA, Goodyear and Prince (2003) estimated that the annual recreational catch of white marlin along the Atlantic and Gulf coasts ranges from 4,000 to 8,000 individuals. Domestic recreational landings of white marlins are currently regulated by a minimum lower-jaw fork length of $168 \mathrm{~cm}$ (66 in). In addition, since 2000 the U.S. Atlantic recreational fishery has been limited to an annual landings quota of 250 blue and white marlins combined (ICCAT Recommendation 00-13). As a result, it is estimated that up to $99 \%$ of white marlin caught in the U.S recreational fishery are now released alive (Goodyear and Prince 2003).

A variety of terminal tackle is used in the offshore recreational fishery for white marlin, including artificial lures, natural baits, and bait-and-lure combinations. Most anglers targeting this species slowly troll dead ballyhoo Hemiramphus brasiliensis at the surface (Jesien et al. 2006). As white marlin approach the trolled baits from behind, many anglers will drop back, manually decreasing the tension on the line (drag) for several seconds to give the fish time to ingest rigged baits without feeling resistance (Jolley 1975; Mather et al. 1975; Prince et al. 2007). Hooks are set by applying tension several seconds after the fish has overtaken and ingested the bait, often resulting in deep hooking and hook-induced injuries to vital internal organs (Horodysky and Graves 2005; Prince et al. 2007). Both separately and together, suboptimal hooking locations and hook-induced trauma greatly reduce postrelease survival of white marlin (Horodysky and Graves 2005).

Previous studies have demonstrated that the use of circle hooks in recreational fisheries targeting piscivorous species can result in substantially lower incidences of deep hooking, hook-induced tissue trauma, and mortality relative to the use of straight-shank (Jtype) hooks (Muoneke and Childress 1994; Cooke and Suski 2004). For white marlin, Horodysky and Graves (2005) reported that circle hooks significantly reduced the incidence of deep hooking and bleeding relative to $\mathrm{J}$ hooks. Furthermore, they noted a significant difference in postrelease survival between white marlin caught on $\mathrm{J}$ hooks $(65 \%)$ and those caught on circle hooks $(100 \%)$. Based on the depleted condition of the white marlin resource and the significant difference in postrelease survival between fish caught on the two hook types, NMFS (2006; as part of its Final Consolidated Highly Migratory Species Fisheries Management Plan) implemented a regulation on 1 January 2007 that required the use of circle hooks when fishing with natural baits in all Atlantic billfish tournaments.

A wide array of circle hook models, encompassing a range of sizes, shapes, and degree of offset between the planes of the hook point and shank, is available to recreational offshore anglers (Cooke and Suski 2004). Prince et al. (2002) demonstrated that frequency of deep hooking in sailfish Istiophorus platypterus increased with the magnitude of circle hook offset; hooks with severe offsets of $15^{\circ}$ had deep hooking percentages similar to those of $\mathrm{J}$ hooks. In some cases, similar outcomes can also result from the use of non- or mildly offset circle hook models in combination with specific fishing practices. For example, Prince et al. (2007) noted that extending dropback times with a circle hook bearing a more traditional J-hook shape resulted in a higher incidence of deep hooking than that associated with a more rounded circle hook, although the trend was not significant. While the effects of different circle hook models on the postrelease survival of white marlin are unknown, it is clear that these data are essential for the development of a meaningful and enforceable management regulation.

In this study, we determined the postrelease survival of white marlin caught on three commonly used circle hook models that differ in shape and offset. In addition to noting hooking location and the condition of the fish at the time of catch, the survival of released fish was monitored for $10 \mathrm{~d}$ after release using pop-up satellite archival tags (PSATs).

\section{Methods}

Three circle hook models commonly used with natural baits in the recreational fishery for white marlin were selected for this study: (1) non-offset Eagle Claw Circle Sea (Model L2004EL; sizes 7/09/0), which has a moderately elongated circular bend; (2) non-offset Owner SSW In-Line Circle Hook (Model 5379-161; size 6/0), which has a bend region shaped more like a J hook; and (3) $5^{\circ}$ offset Mustad Demon Fine Wire (Model C39952BL; size 7/0), which has a circular bend (Figure 1). Two of these circle hook models (Eagle Claw and Mustad) were employed by Horodysky and Graves (2005) in their comparison of postrelease survival of white marlin caught on J hooks and circle hooks. The results from those 20 fish caught on circle hooks (11 fish on Eagle Claw; 9 fish on Mustad) are incorporated into this analysis. Numerous rigging techniques were used to attach the circle hooks 


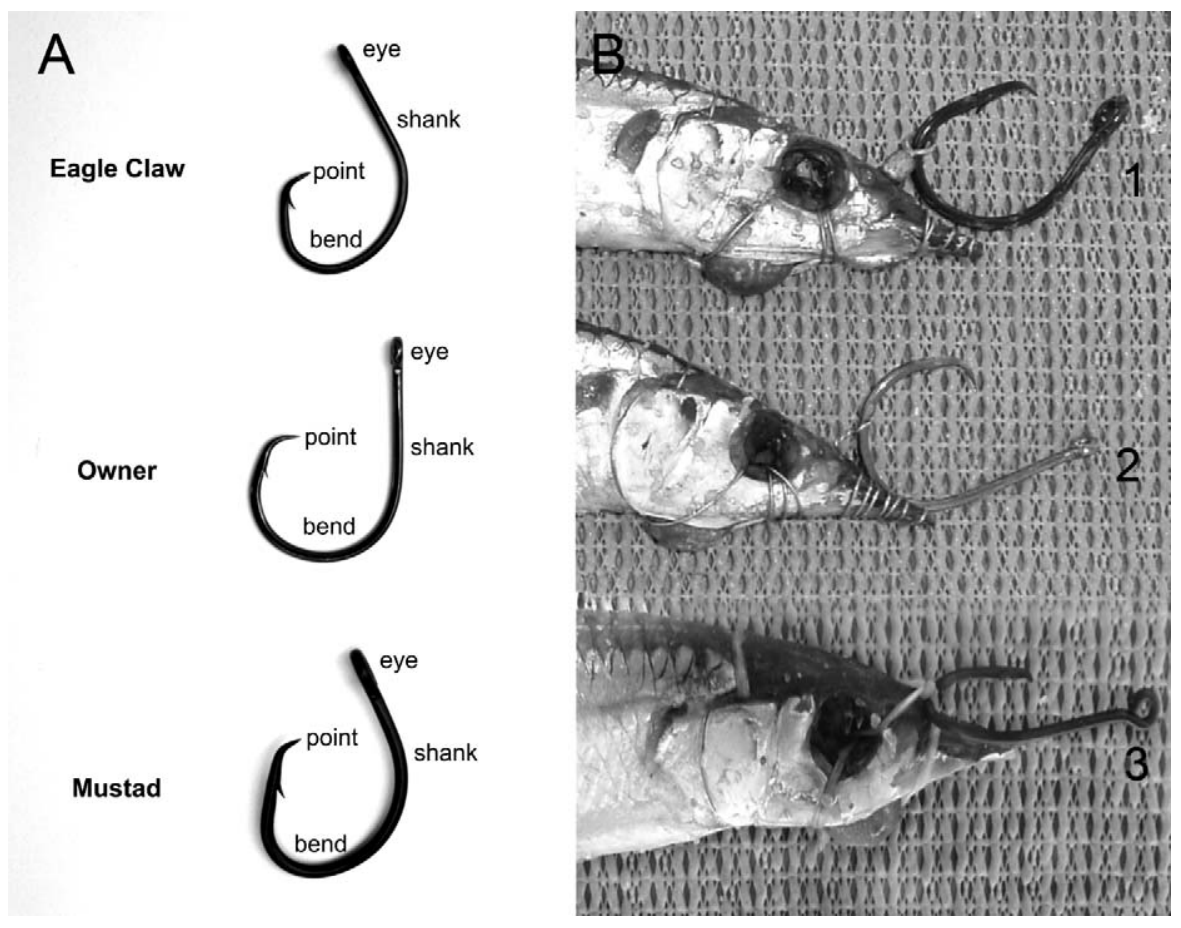

FIGURE 1.-Circle hooks and rigging types used in a study of white marlin postrelease mortality along the Atlantic coast, 2002-2006: (A) three circle hook models commonly used in the recreational fishery: Eagle Claw (Model L2004EL; sizes 7/0-9/ 0) non-offset hook with a moderately elongated, circular bend; Owner (Model 5379-161; size 6/0) non-offset hook with a bend region similar to that of traditional straight-shank (J) hooks; and Mustad (Model C39952BL; size 7/0), $5^{\circ}$ offset hook with a circular bend; and (B) three methods of rigging commonly used to attach any of the three circle hook models to ballyhoo baits: (1) wire harness with a barrel swivel, (2) plain wire harness, and (3) a rigging floss harness.

to the ballyhoo bait (wire harness attached to a barrel swivel, plain wire harness, rigging floss harness), but all methods left the circle hook exposed on the top of the head of the bait (Figure 1). Typically, we fished one model of circle hook per vessel per day.

White marlin were caught, tagged, and released between November 2002 and November 2006 in waters off Cape May, New Jersey; Virginia Beach, Virginia; and Manteo, North Carolina, along the U.S. mid-Atlantic coast (fish codes beginning with MA); Isla Mujeres, Mexico (MX); and La Guaira, Venezuela (VZ; Table 1). As white marlin attacked the trolled ballyhoos, the bait was dropped back for 4-10 s, a typical practice in the mid-Atlantic white marlin fishery (Jesien et al. 2006). Fish were caught on 20-30-lb-class sportfishing tackle using 60-80-lb-test leaders that were $1-2 \mathrm{~m}$ in length. Fight times were consistent for the fishery, usually 5-30 min. In some instances, a fight was prolonged to ensure that the white marlin was sufficiently calm before it was brought next to the boat, a practice that facilitated accurate tag placement. A cursory examination of each white marlin was undertaken prior to tagging to note the condition of the animal and hook location. We used the binary hooking location designations of Horodysky and Graves (2005) in this study: (1) externally visible hooking included hooking in the jaw corner (JC), lower jaw (LJ), caudal fin (CF), bill (BL), and branchiostegal membrane (BR) and (2) deep (not externally visible). We tagged the first 60 fish available to us.

Fish were tagged with Microwave Telemetry PTT 100 HR PSATs programmed for release (pop-up) after

TABLE 1.-Summary of white marlin pop-up satellite archival tag deployment periods and locations along the Atlantic coast. Tags were used to assess differences in postrelease survival among fish caught on three hook types.

\begin{tabular}{clc}
\hline \multicolumn{1}{c}{ Location } & $\begin{array}{c}\text { Tagging month } \\
\text { and year }\end{array}$ & Number deployed \\
\hline \multirow{2}{*}{ Mid-Atlantic coast, USA } & Sep 2005 & 7 \\
& Jul-Sep 2006 & 12 \\
Isla Mujeres, Mexico & Jun 2003 & 3 \\
& May-Jun 2006 & 3 \\
La Guaira, Venezuela & Nov 2002 & 6 \\
& Sep-Oct 2003 & 11 \\
& Nov 2005 & 7 \\
& Sep 2006 & 11 \\
\hline
\end{tabular}


$10 \mathrm{~d}$. This tag model records temperature, pressure (depth), and light levels approximately every 90-120 s; upon surfacing, it transmits the unprocessed data to satellites of the Argos system. The rigging and deployment of PSATs followed the protocols presented by Graves et al. (2002) and Horodysky and Graves (2005), respectively.

Survival of released white marlin was inferred from temperature and depth profiles as well as net movement from the release point to the location of the surfaced tag's first transmission by following the protocols of Horodysky and Graves (2005). Cochran-MantelHaenszel (CMH) tests were used to address the effect of the different circle hook models on survival, hooking location, and the degree of hook-induced trauma. A Yates correction for small sample size was applied when expected cell values were less than 5 (Agresti 1990). All statistical analyses were conducted in the Statistical Analysis System version 9.1 (SAS Institute, Cary, North Carolina). Bootstrapping simulations were performed to determine effect of sample size on the $95 \%$ confidence intervals of the release mortality estimates using software developed by Goodyear (2002). Distributions of estimates were based on 10,000 simulations and assumed (1) an underlying release mortality that was equivalent to mortality observed for the three circle hook models and (2) no sources of error in mortality (e.g., no premature release of tags, no tagging-induced mortality, and no natural mortality).

\section{Results}

Twenty white marlin were caught on each of the three circle hook models, tagged with Microwave Telemetry PSATs, and released. Nineteen white marlin were released off the U.S. mid-Atlantic coast; 6 were released off Isla Mujeres, Mexico; and 35 were released off La Guaira, Venezuela (Table 2). The estimated size of released fish ranged from 16 to $41 \mathrm{~kg}$ (average size $=22.5 \mathrm{~kg}$ ). Fight times (including the tag application procedure) ranged from 4 to $40 \mathrm{~min}$; average fight and tag deployment time was just over 13 min.

Of the 60 white marlin caught on circle hooks in this study, $59(98.3 \%)$ were hooked in externally visible locations and $55(91.7 \%)$ of these were hooked in the jaw (Table 2; Figure 2). All three circle hook models preferentially hooked fish in the corner of the jaw (Eagle Claw: 100\%; Owner: 90\%; Mustad: 70\%). Two white marlin were hooked under the bill, one on an Owner hook (VZ05-05), and one on a Mustad hook (VZ06-02). Two fish were foul hooked, one in the branchiostegal membrane with an Owner hook (VZ0504) and the other in the caudal fin with a Mustad hook

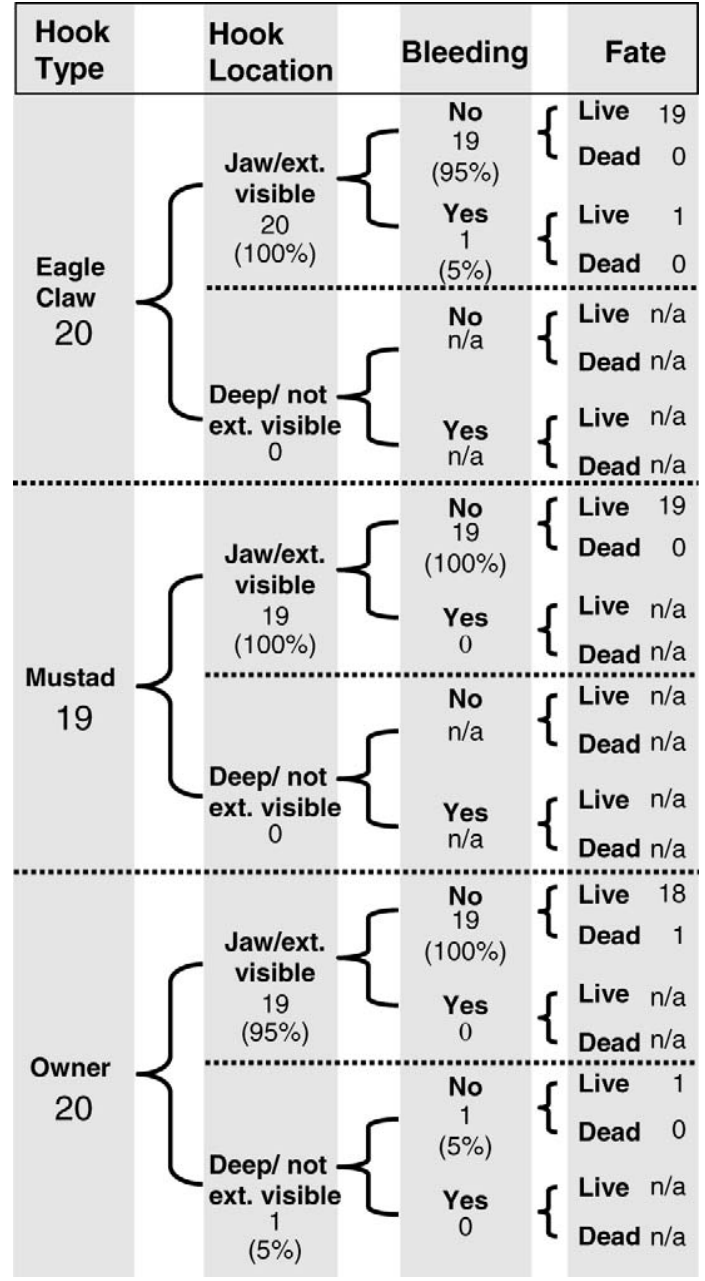

FIGURE 2.-Effects of three circle hook models on hooking location (externally visible or deep [not externally visible] hooking), bleeding (presence or absence), and fate (alive or dead at the end of a 5-10-d tracking period) of white marlin fitted with pop-up satellite archival tags in 2002-2006 (na = not applicable).

(MX06-01). The only deeply hooked white marlin (MA06-12) was caught on an Owner circle hook that lodged in the palate. None of the 60 fish exhibited major hook-induced trauma. The lone white marlin observed bleeding in this study (VZ03-04) was caught on a 9/0 Eagle Claw hook that punctured the orbit but not the eye. One additional fish (VZ05-6) appeared to suffer recent trauma not induced by a hook; a fresh circular wound on its flank was most likely the result of a bite from a cookiecutter shark Isistius brasiliensis.

All 60 Microwave Telemetry PSATs transmitted data to Argos satellites upon the tags' release from study animals. Three tags detached from their hosts 
TABLE 2.- Summary information for white marlin caught on three hook types (MU = Mustad; EC = Eagle Claw; OW = Owner), tagged with pop-up satellite archival tages, and released in the western North Atlantic Ocean. Fight time includes the tagging process and resuscitation (R), where applicable. Hook locations are jaw corner (JC), lower jaw (LJ), caudal fin (CF), bill (BL), branchiostegal membrane (BR), and deep (DP). Bleeding at the time of release was noted as present (yes [Y]) or absent (no $[\mathrm{N}]$ ); fate at 5-10 d postrelease is coded as live (L) or dead (D). The first 20 fish in the table (codes beginning with VZ02, MX03, and VZ03) were previously reported by Horodysky and Graves (2005).

\begin{tabular}{|c|c|c|c|c|c|c|c|c|}
\hline \multirow[b]{2}{*}{ Fish code ${ }^{\mathrm{a}}$} & \multirow{2}{*}{$\begin{array}{c}\text { Estimated } \\
\text { weight }(\mathrm{kg})\end{array}$} & \multirow{2}{*}{$\begin{array}{l}\text { Fight time } \\
\text { (min) }\end{array}$} & \multirow[b]{2}{*}{ Hook type } & \multirow{2}{*}{$\begin{array}{c}\text { Hook } \\
\text { location }\end{array}$} & \multirow[b]{2}{*}{ Bleeding } & \multirow[b]{2}{*}{ Fate } & \multicolumn{2}{|c|}{ Movement $^{\mathrm{b}}$} \\
\hline & & & & & & & $\mathrm{km}$ & $\mathrm{nmi}$ \\
\hline VZ02-01 & 27 & 9 & MU & $\mathrm{JC}$ & $\mathrm{N}$ & L & 219 & 118 \\
\hline VZ02-02 & 23 & 13 & MU & LJ & $\mathrm{N}$ & $\mathrm{L}$ & 148 & 80 \\
\hline VZ02-03 (R) & 20 & 6 & MU & $\mathrm{JC}$ & $\mathrm{N}$ & $\mathrm{L}$ & 128 & 69 \\
\hline VZ02-04 & 18 & 10 & MU & LJ & $\mathrm{N}$ & $\mathrm{L}$ & 117 & 63 \\
\hline VZ02-05 & 20 & 8 & MU & LJ & $\mathrm{N}$ & $\mathrm{L}$ & 124 & 67 \\
\hline VZ02-06 & 23 & 10 & MU & LJ & $\mathrm{N}$ & L & 181 & 98 \\
\hline MX03-01 & 27 & 16 & MU & $\mathrm{JC}$ & $\mathrm{N}$ & $\mathrm{L}$ & 319 & 172 \\
\hline MX03-02 & 18 & 15 & $\mathrm{EC}$ & $\mathrm{JC}$ & $\mathrm{N}$ & $\mathrm{L}$ & 782 & 422 \\
\hline MX03-03 (R) & 23 & 26 & $\mathrm{EC}$ & $\mathrm{JC}$ & $\mathrm{N}$ & $\mathrm{L}$ & 391 & 211 \\
\hline VZ03-01 & 20 & 4 & $\mathrm{EC}$ & $\mathrm{JC}$ & $\mathrm{N}$ & L & 157 & 85 \\
\hline VZ03-02 & 30 & 7 & $\mathrm{EC}$ & $\mathrm{JC}$ & $\mathrm{N}$ & $\mathrm{L}$ & 235 & 127 \\
\hline VZ03-03 & 23 & 13 & $\mathrm{EC}$ & $\mathrm{JC}$ & $\mathrm{N}$ & $\mathrm{L}$ & 30 & 16 \\
\hline VZ03-04 & 27 & 11 & $\mathrm{EC}$ & $\mathrm{JC}$ & $\mathrm{Y}$ & $\mathrm{L}$ & 211 & 114 \\
\hline VZ03-05 & 34 & 24 & $\mathrm{EC}$ & $\mathrm{JC}$ & $\mathrm{N}$ & L & 74 & 40 \\
\hline VZ03-06 & 23 & 10 & $\mathrm{EC}$ & $\mathrm{JC}$ & $\mathrm{N}$ & $\mathrm{L}$ & 91 & 49 \\
\hline VZ03-07 & 23 & 16 & $\mathrm{EC}$ & $\mathrm{JC}$ & $\mathrm{N}$ & L & 43 & 23 \\
\hline VZ03-08 & 23 & 8 & $\mathrm{EC}$ & $\mathrm{JC}$ & $\mathrm{N}$ & L & 72 & 39 \\
\hline VZ03-09 & 23 & 11 & $\mathrm{EC}$ & $\mathrm{JC}$ & $\mathrm{N}$ & L & 235 & 127 \\
\hline VZ03-14 & 20 & 15 & MU & $\mathrm{JC}$ & $\mathrm{N}$ & $\mathrm{L}$ & 243 & 131 \\
\hline VZ03-15 & 20 & 9 & $\mathrm{MU}$ & $\mathrm{JC}$ & $\mathrm{N}$ & L & 237 & 128 \\
\hline MA05-01 & 23 & 11 & OW & $\mathrm{JC}$ & $\mathrm{N}$ & L & 269 & 145 \\
\hline MA05-02 & 20 & 14 & OW & $\mathrm{JC}$ & $\mathrm{N}$ & D & 280 & 151 \\
\hline MA05-03 & 25 & 18 & OW & $\mathrm{JC}$ & $\mathrm{N}$ & $\mathrm{L}$ & 801 & 433 \\
\hline MA05-04 & 30 & 12 & OW & $\mathrm{JC}$ & $\mathrm{N}$ & L & 329 & 178 \\
\hline MA05-05 & 25 & 12 & OW & $\mathrm{JC}$ & $\mathrm{N}$ & $\mathrm{L}$ & 239 & 129 \\
\hline MA05-06 & 27 & 16 & OW & $\mathrm{JC}$ & $\mathrm{N}$ & L & 633 & 342 \\
\hline MA05-07 & 23 & 5 & OW & $\mathrm{JC}$ & $\mathrm{N}$ & $\mathrm{L}$ & 123 & 82 \\
\hline VZ05-01 & 16 & 15 & OW & JC & $\mathrm{N}$ & $\mathrm{L}$ & 224 & 121 \\
\hline VZ05-02 & 20 & 40 & OW & $\mathrm{JC}$ & $\mathrm{N}$ & $\mathrm{L}$ & 102 & 55 \\
\hline VZ05-03 & 18 & 18 & OW & $\mathrm{JC}$ & $\mathrm{N}$ & $\mathrm{L}$ & 296 & 160 \\
\hline VZ05-04 & 20 & 26 & OW & BR & $\mathrm{N}$ & $\mathrm{L}$ & 298 & 161 \\
\hline VZ05-05 & 18 & 5 & OW & $\mathrm{JC}$ & $\mathrm{N}$ & $\mathrm{L}$ & 172 & 93 \\
\hline VZ05-06 & 23 & 5 & $\mathrm{EC}$ & $\mathrm{JC}$ & $\mathrm{N}$ & $\mathrm{L}$ & 83 & 45 \\
\hline VZ05-07 & 20 & 8 & $\mathrm{EC}$ & $\mathrm{JC}$ & $\mathrm{N}$ & L & 233 & 126 \\
\hline MX06-01 & 23 & 20 & MU & $\mathrm{CF}$ & $\mathrm{N}$ & $\mathrm{L}$ & 725 & 392 \\
\hline MX06-02 & 18 & 15 & MU & $\mathrm{JC}$ & $\mathrm{N}$ & $\mathrm{L}$ & 239 & 129 \\
\hline MX06-03 & 25 & 21 & MU & $\mathrm{JC}$ & $\mathrm{N}$ & $\mathrm{L}$ & 398 & 215 \\
\hline MA06-01 & 23 & 20 & $\mathrm{EC}$ & $\mathrm{JC}$ & $\mathrm{N}$ & $\mathrm{L}$ & 487 & 263 \\
\hline MA06-02 & 18 & 5 & $\mathrm{EC}$ & $\mathrm{JC}$ & $\mathrm{N}$ & $\mathrm{L}$ & 864 & 467 \\
\hline MA06-03 & 18 & 14 & MU & $\mathrm{JC}$ & $\mathrm{N}$ & L & 408 & 272 \\
\hline MA06-04 & 20 & 15 & $\mathrm{MU}$ & $\mathrm{JC}$ & $\mathrm{N}$ & L & 81 & 44 \\
\hline MA06-05 & 23 & 15 & OW & $\mathrm{JC}$ & $\mathrm{N}$ & $\mathrm{L}$ & 131 & 71 \\
\hline MA06-06 & 20 & 12 & OW & $\mathrm{JC}$ & $\mathrm{N}$ & L & 357 & 193 \\
\hline MA06-07 & 20 & 15 & MU & $\mathrm{JC}$ & $\mathrm{N}$ & $\mathrm{L}$ & 93 & 50 \\
\hline MA06-08 & 23 & 15 & OW & $\mathrm{JC}$ & $\mathrm{N}$ & L & 152 & 82 \\
\hline MA06-09 & 20 & 40 & OW & $\mathrm{JC}$ & $\mathrm{N}$ & $\mathrm{L}$ & 754 & 408 \\
\hline MA06-10 & 23 & 15 & OW & $\mathrm{JC}$ & $\mathrm{N}$ & $\mathrm{L}$ & 131 & 71 \\
\hline MA06-11 & 23 & 12 & OW & $\mathrm{JC}$ & $\mathrm{N}$ & $\mathrm{L}$ & 592 & 320 \\
\hline MA06-12 & 25 & 10 & OW & DP & $\mathrm{N}$ & L & 144 & 78 \\
\hline VZ06-01 & 23 & 9 & MU & $\mathrm{JC}$ & $\mathrm{N}$ & $\mathrm{L}$ & 30 & 16 \\
\hline VZ06-02 & 23 & 14 & MU & BL & $\mathrm{N}$ & L & 122 & 66 \\
\hline VZ06-03 & 18 & 5 & MU & $\mathrm{JC}$ & $\mathrm{N}$ & $\mathrm{L}$ & 180 & 97 \\
\hline VZ06-04 & 41 & 17 & $\mathrm{EC}$ & $\mathrm{JC}$ & $\mathrm{N}$ & L & 68 & 37 \\
\hline VZ06-05 & 20 & 7 & $\mathrm{EC}$ & $\mathrm{JC}$ & $\mathrm{N}$ & $\mathrm{L}$ & 109 & 59 \\
\hline VZ06-06 & 27 & 12 & $\mathrm{EC}$ & $\mathrm{JC}$ & $\mathrm{N}$ & $\mathrm{L}$ & 72 & 39 \\
\hline VZ06-07 & 23 & 5 & $\mathrm{EC}$ & $\mathrm{JC}$ & $\mathrm{N}$ & $\mathrm{L}$ & 22 & 12 \\
\hline VZ06-08 & 20 & 8 & MU & $\mathrm{JC}$ & $\mathrm{N}$ & $\mathrm{L}$ & 157 & 85 \\
\hline VZ06-09 & 25 & 13 & MU & $\mathrm{JC}$ & $\mathrm{N}$ & - & 310 & 168 \\
\hline VZ06-10 & 18 & 15 & MU & $\mathrm{JC}$ & $\mathrm{N}$ & $\mathrm{L}$ & 276 & 149 \\
\hline VZ06-11 & 20 & 6 & OW & $\mathrm{JC}$ & $\mathrm{N}$ & $\mathrm{L}$ & 305 & 165 \\
\hline
\end{tabular}

\footnotetext{
${ }^{a}$ Codes indicate the area of capture: $\mathrm{VZ}=$ Venezuela, $\mathrm{MX}=$ Mexico, MA = mid-Atlantic coast of USA.
}

${ }^{\mathrm{b}}$ Net displacement of fish during the tracking period is given in kilometers $(\mathrm{km})$ and nautical miles (nmi). 
prior to the $10-\mathrm{d}$ programmed release: one after $1 \mathrm{~d}$ (VZ06-09) and two after $5 \mathrm{~d}$ (VZ05-04 and VZ06-02). Five days has been considered a sufficient time period for the expression of relevant sources of postrelease mortality (Graves et al. 2002); therefore, we decided to include the data from the two tags that remained attached for $5 \mathrm{~d}$ in subsequent analyses. Tag VZ06-09 released prematurely after approximately $1 \mathrm{~d}$, and the first signal location was $310 \mathrm{~km}$ from the point of release. Despite the large net displacement, we felt that $1 \mathrm{~d}$ of information after release was not sufficient to determine survival, and this fish was eliminated from subsequent analyses. Consequently, our sample size for the Mustad hook was only 19 individuals. The PSATs typically transmit less than $100 \%$ of the stored data for a variety of reasons, including limited battery life, sea state, and biological interactions. In this study, transmission of the archived data from each tag ranged from $24 \%$ to $79 \%$ (mean $=62 \%$ ).

Temperature-depth profiles and net displacement data suggested that 58 of 59 tagged white marlin $(98.3 \%)$ survived recreational release. Surviving fish made repeated daily vertical excursions of up to 200-m depth throughout the tag deployment duration. Furthermore, the net movement of these fish from the release point to the location of the first tag transmission was consistent with that expected for actively swimming animals (Horodysky et al. 2007). The single inferred mortality in this study (MA05-02) was caught on an Owner circle hook that lodged in the center of the fish's lower jaw. The white marlin had a fight time of $14 \mathrm{~min}$ and was considered to be in excellent condition (based on coloration, movement, lack of visible injuries) at the time of release. Like many white marlin released off the U.S. mid-Atlantic coast, this animal spent the first few days after release in the upper $30 \mathrm{~m}$ of the water column. However, during the fourth day after release, the tag (and presumably the animal, as the tag is positively buoyant) sank to the ocean bottom at $1,160 \mathrm{~m}$ and remained there for $4 \mathrm{~d}$ until it released from the fish and floated to the surface.

Due to the limited number of negative impacts on white marlin caught on the three circle hooks types (one mortality, one deeply hooked fish, one bleeding fish), no statistically significant differences were evident in hooking location, hook-induced trauma, or mortality among fish caught on the circle hook models. Since the null hypothesis of no difference between hook types could not be rejected, data from all three models were thus pooled to generate an overall postrelease mortality rate of $1.7 \%$ for this terminal gear type. Using the model developed by Goodyear (2002), the results of 10,000 simulated experiments at an underlying true mortality rate of $1.7 \%$ indicate that more than 80 PSATs would have to be deployed to reduce the confidence intervals to $\pm 5 \%$. In our study, in which 59 tags were deployed on white marlin caught on non- or minor-offset circle hooks, the approximate confidence intervals for mortality estimates ranged from $0 \%$ to $6 \%$ in the absence of any confounding factors.

\section{Discussion}

All 60 PSATs deployed in this study detached from the white marlin and transmitted to Argos satellites. Most studies applying satellite tags to istiophorid billfishes and other large pelagic fishes have experienced one or more instances of tag reporting failure, and reporting rates tend to decrease with tag deployment duration (Graves et al. 2002; Domeier et al. 2003; Kerstetter et al. 2004; Kerstetter and Graves 2006). Nonreporting can result from tag mechanical failure, biological interactions, or fishery gear interactions (Graves et al. 2002; Hoolihan 2004; Kerstetter et al. 2004). The interpretation of such nonreporting tags can be problematic for studies of postrelease survival, as survival rates are biased upwards by eliminating nonreporting tags from analyses and are biased downwards when all nonreporting tags are assumed to represent mortalities (Goodyear 2002; Kerstetter and Graves 2006). In this study, we used short deployment durations to minimize the incidence of nonreporting tags and the ambiguities associated with their interpretation. The tagging duration was selected to account for most sources of mortality associated with the capture event while minimizing other potential sources of natural and additional fishing (e.g., recapture) mortalities that could confound our results (Goodyear 2002; Graves et al. 2002; Kerstetter et al. 2004).

Fifty-seven of the 60 PSATs $(95 \%)$ deployed in this study remained attached to the white marlin for the full 10-d deployment duration. As previously stated, tag VZ06-09 was attached for approximately $24 \mathrm{~h}$ and was eliminated from this study. The two remaining tags (VZ05-04 and VZ06-02) prematurely released on the fifth day after deployment; these two white marlin exhibited a pattern of several deep dives during each of the $5 \mathrm{~d}$ at liberty, similar to other surviving white marlin in that area. The majority of white marlin mortalities noted from the recreational and pelagic longline fisheries have occurred shortly after release, and in only a few instances have mortalities occurred after $48 \mathrm{~h}$ (Horodysky and Graves 2005; Kerstetter and Graves 2006). Based on these data, we assumed that these two individuals survived their encounters with recreational fishing gear.

We did not detect a significant difference in hooking location of white marlin between non-offset (Eagle 
Claw, Owner) and minor-offset (Mustad) circle hooks. Only 1 of the 59 white marlin considered in this study was deeply hooked, and this fish was caught on a nonoffset Owner circle hook. In a study of 75 Atlantic sailfish caught on live baits rigged with non-offset, slightly offset $\left(4^{\circ}\right)$, or severely offset $\left(15^{\circ}\right)$ circle hooks, Prince et al. (2002) demonstrated that circle hooks possessing minor or no offset were strongly associated with external hooking locations and little trauma, whereas severely offset hooks were associated with deep hooking and bleeding. Our results are consistent with the observation that non-offset and minor-offset $\left(\leq 5^{\circ}\right)$ circle hooks have a very low incidence of deep hooking.

The differing degree of offset used in this study likewise did not significantly affect hook-induced trauma. The single white marlin that suffered hookinduced trauma resulting in bleeding (VZ03-04) was caught on a 9/0 non-offset Eagle Claw hook that punctured the orbit but did not damage the eye. Ocular trauma has been reported for a variety of fishes caught on circle hooks, including bluegills Lepomis macrochirus, Chinook salmon Oncorhynchus tshawytscha, bluefin tuna Thunnus thynnus, striped marlin Tetrapturus audax (revised to K. audax), and white marlin (Grover et al. 2002; Skomal et al. 2002; Cooke et al. 2003; Domeier et al. 2003; Kerstetter and Graves 2006). Circle hook size relative to fish size may be an important consideration for optimum performance and conservation benefit of circle hooks (Cooke et al. 2003). Hook-induced eye trauma may be more likely with the use of larger circle hooks for the target quarry (Skomal et al. 2002), as was the case in our study. The distance between the hook eye and bend of the $9 / 0$ Eagle Claw hook approximates the distance between the corner of the mouth and the eye socket of most white marlin, and we did not observe eye trauma with smaller hook sizes (6/0-8/0). Larger circle hooks (16/0 and 18/0) employed in the pelagic longline fishery also cause ocular trauma. Kerstetter and Graves (2006) reported that 8 of 19 white marlin $(42.1 \%)$ were hooked near the eye: 6 in the eye socket and 2 in the eye proper. Seven of the eight PSATs attached to these fish transmitted to satellites after $10 \mathrm{~d}$, and the data from all seven were consistent with survival over the tag deployment duration. The conservation benefits of circle hooks will be lessened if eye damage resulting from the hook causes bleeding or impaired vision, which could increase the likelihood of delayed mortality due to reduced foraging capacity, increased risk of predation, or disease (Cooke and Suski 2004).

The lone mortality inferred in this study (MA05-02) occurred on the fifth day after release. Most postrelease mortalities in billfishes have occurred within the first 24-48 h after release (Domeier et al. 2003; Horodysky and Graves 2005; Kerstetter and Graves 2006); however, delayed mortalities have been observed with PSATs. Reasons for longer-term mortalities are poorly understood but may include physiological stress associated with catch and release, infection, predation, and natural mortality (Wood et al. 1983; Bourke et al. 1987; Kerstetter et al. 2004). Fish MA05-02 was caught on an Owner circle hook that lodged in the center of the lower jaw, presumably a nonlethal location. Circle hooks are defined as having the point perpendicular to the shaft (Cooke and Suski 2004), and by this definition the Owner hook is a circle hook (Figure 1). As has been suggested for J hooks, it is possible that the Owner circle hook may have damaged vital soft tissues before lodging in the lower jaw (Prince et al. 2002; Horodysky and Graves 2005). This same model was also responsible for the single incidence of deep hooking observed (MA06-12, hooked in the palate). Prince et al. (2007) employed the same Owner and Eagle Claw models used in this study to evaluate the incidence of deep hooking in sailfish caught on live bait off Florida's eastern coast. They compared the performance of these hooks at four different dropback treatments $(0-5,6-10,11-15$, and $>15 \mathrm{~s}$ ) and reported a higher proportion of hooking in "undesirable locations" for the Owner hook at all four dropback intervals, although the differences were not statistically significant. Combined, the trends noted in Prince et al. (2007) and the present study suggest that the shape of a circle hook may be more important for the maximum conservation benefit than previously appreciated.

There was no apparent difference in postrelease mortality observed between white marlin caught on non- and slightly offset circle hooks. This finding is consistent with that of Domeier et al. (2003), who reported no significant difference in the rate of postrelease survival of striped marlin caught on live baits with offset and slightly offset $\left(5^{\circ}\right)$ circle hooks. While not able to investigate postrelease survival, Prince et al. (2002) noted a significant increase in the proportion of deep hooking events in sailfish caught on severely offset $\left(15^{\circ}\right)$ circle hooks relative to those caught on non- or slightly offset circle hooks.

While we observed no major differences in hooking location or postrelease mortality among white marlin caught on the three circle hook models used in this study, the pooled circle hook data exhibited a significant decrease in the incidence of deep (internal) hooking (Yates' corrected CMH: $\chi^{2}=26.4, P<$ $0.0001)$, hook-induced trauma $\left(\chi^{2}=22.6, P<0.0001\right)$, and postrelease mortality $\left(\chi^{2}=15.5, P<0.0001\right)$ 
relative to white marlin caught on $\mathrm{J}$ hooks under similar conditions (Horodysky and Graves 2005). Odds ratios revealed that $\mathrm{J}$ hooks were 38 times more likely to hook fish deeply, 31 times more likely to induce trauma, and 20 times more likely to cause mortality than were circle hooks. These data are consistent with the results of Prince et al. (2002), who reported that Pacific sailfish caught on dead natural baits rigged with circle hooks had significantly lower rates of deep hooking and bleeding than did fish caught on baits rigged with J hooks. Similarly, Domeier et al. (2003) noted a trend for decreased rates of bleeding and postrelease survival of striped marlin caught on live natural baits rigged with circle hooks relative to those caught on $\mathrm{J}$ hooks, although the differences were not statistically significant.

The difference in postrelease mortality resulting from the use of circle or $\mathrm{J}$ hooks in the white marlin recreational fishery can have a considerable impact on this overfished stock. We observed 1 mortality among the 59 white marlin caught on all circle hook models ( $1.7 \%$ postrelease mortality) in this study, whereas 7 mortalities among the 20 white marlin caught on $\mathrm{J}$ hooks (35\% postrelease mortality) were observed by Horodysky and Graves (2005). It is estimated that recreational anglers along the U.S. Atlantic and Gulf coasts catch between 4,000 and 8,000 white marlin each year (Goodyear and Prince 2003); the vast majority of these are caught on natural baits with $\mathrm{J}$ hooks and are then released. If all white marlin taken in the U.S. recreational fishery were caught only on $\mathrm{J}$ hooks, a postrelease mortality range of 1,400-2,800 individuals would result (Figure 3). Alternately, only 68-136 postrelease mortalities would be expected from the exclusive use of circle hooks in this fishery.

On 1 January 2007, NMFS implemented a domestic management measure requiring the use of non-offset circle hooks for all participants fishing with natural baits in Atlantic billfish tournaments (NMFS 2006). Between 1999 and 2004, the number of white marlin released each year by U.S. Atlantic billfish tournaments ranged from 614 to 2,207 individuals (NMFS 2006). If all white marlin caught in these tournaments were taken on $\mathrm{J}$ hooks that result in $35 \%$ postrelease mortality (Horodysky and Graves 2005), then 215-772 postrelease mortalities would be expected annually (Figure 3). Alternately, if all tournament-released white marlin were caught on circle hooks that result in a postrelease mortality of $1.7 \%$ (this study), then 10-38 postrelease mortalities would be expected. In other words, perfect compliance with the NMFS management measure during those years could have decreased white marlin postrelease mortality in U.S. billfish tournaments by 205-734 individuals per year. The

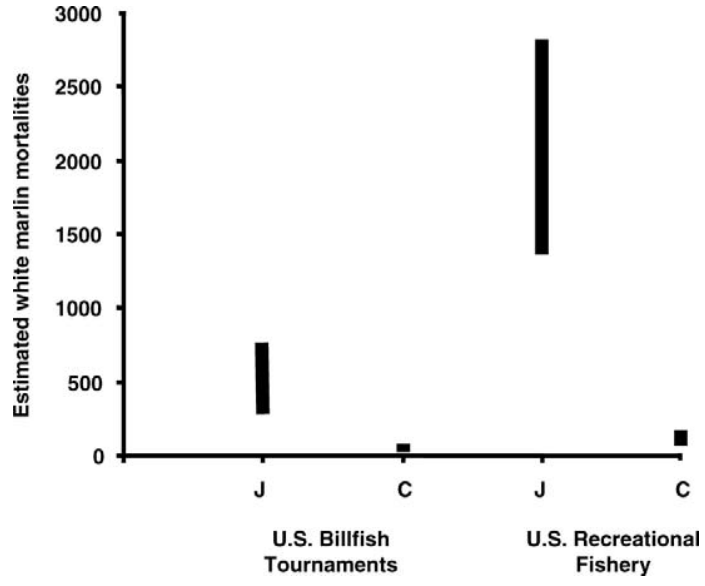

FIGURE 3.-Estimated range of white marlin postrelease mortalities associated with the use of $\mathrm{J}$ hooks $(\mathrm{J})$ and circle hooks (C) in U.S. billfish tournaments and the overall U.S. recreational fishery; estimates were calculated by applying postrelease mortality estimates (35\% for J: Horodysky and Graves $2005 ; 1.7 \%$ for C: this study) to annual white marlin release estimates (614-2,207 from tournaments: National Marine Fisheries Service Recreational Billfish Survey, unpublished data; 4,000-8,000 from the fishery: Goodyear and Prince 2003).

conservation benefit accruing from the regulatory action would probably be enhanced by effort outside of registered billfish tournaments, as many offshore anglers that target white marlin and that fish in billfish tournaments will probably use circle hooks during nontournament periods to improve their angling techniques.

If NMFS had elected to mandate the use of circle hooks in natural baits for all U.S. recreational offshore anglers rather than only those in registered billfish tournaments, then the annual reduction in white marlin postrelease fishing mortality resulting from the U.S. recreational fishery alone would be 1,332-2,664 individuals. Large recreational fisheries that release a significant fraction of the white marlin catch also exist in several other locations throughout the Atlantic (Venezuela, Dominican Republic, Brazil, Azores, and Morocco), and the use of circle hooks in these fisheries could dramatically reduce Atlantic-wide recreational fishing mortality in this overfished stock.

Not all U.S. offshore recreational anglers that catch white marlin target that species. Comments in response to a NMFS Issues and Options Document that included a circle hook requirement for all offshore anglers as an option clearly demonstrated the concern of some anglers that implementation of a requirement to use circle hooks with natural baits in areas where white marlin occur could reduce catches of target species 
such as tunas and dolphinfish (NMFS 2006). Data elucidating the performance of circle and $\mathrm{J}$ hooks in these fisheries are clearly needed to evaluate these anecdotal concerns. However, delays in implementing voluntary or required circle hook use to evaluate such claims will lead to continued use of J hooks in the U.S. recreational fishery and thus will perpetuate high levels of white marlin postrelease mortality.

It is our impression that enforcement of a domestic management measure requiring the use of circle hooks, whether in billfish tournaments or in all offshore recreational fisheries, will be difficult. As noted by Ditton (2002), the potential reduction in billfish recreational fishing mortality resulting from the use of circle hooks will only be realized if there is general acceptance of the conservation benefits of circle hooks by the recreational fishing community. Consequently, circle hook use may be more easily and effectively achieved through angler education and outreach programs rather than through federal mandate.

The results of this study suggest that there are no major differences in hooking location, hook-induced trauma, or postrelease survival among white marlin caught on three circle hook models differing in shape and limited degree of offset that are commonly used in the white marlin recreational fishery. However, relative to white marlin caught on $\mathrm{J}$ hooks, these circle hook models produced a significant reduction in postrelease mortality of recreationally caught fish. Current domestic management measures requiring the use of circle hooks with natural baits in Atlantic billfish tournaments will substantially reduce U.S. recreational fishing mortality of white marlin. However, the magnitude of this conservation benefit is but a fraction of what could be gained by the use of circle hooks in all Atlantic recreational fisheries that target this highly overfished resource. Obtaining international consensus on such a measure through ICCAT is a possibility, although simply having member nations report their recreational catch and effort statistics has been a challenge for this regional fishery management organization. Nonetheless, precedent exists for some nations to proactively implement circle hook regulations; the governments of Guatemala and Costa Rica both require the mandatory use of circle hooks with natural baits in recreational fisheries targeting Pacific sailfish (Cooke and Suski 2004). Management measures aside, white marlin recreational fishing mortality may be most effectively reduced by convincing recreational anglers, who have already demonstrated a strong conservation ethic by voluntarily promoting catch and release of these fish, to employ a terminal gear that maximizes survival of the released animal.

\section{Acknowledgments}

This study greatly benefited from the insights and efforts of Guy Harvey. We thank Dick Weber, Ken Neill, Bill Hudgins, and Bob DeGabrielle for allowing us to conduct our research on their vessels at reduced or no cost. Captains Mike Adkins, Ken Neill, Bill Hudgins, Bubba Carter, Jimmy Grant, and O. B. O'Bryan not only put us on to fish but also expertly maneuvered their boats to facilitate deployment of the satellite tags. A special thanks to Luis Angel Rincon and the crew at Mango Marina for logistic support in Venezuela. We acknowledge the Eagle Claw Corporation for their donation of hooks. This project was supported by funding from NMFS (NA04NMF4540411) to the Gulf States Marine Fisheries Commission (Billfish-2005-11) and the NMFS Highly Migratory Species Management Division (NA05NMF4721107). This is Virginia Institute of Marine Science contribution number 2849.

\section{References}

Agresti, A. 1990. Categorical data analysis. Wiley, New York. Bourke, R. E., J. Brock, and R. M. Nakamura. 1987. A study of delayed capture mortality syndrome in skipjack tuna, Katsuwonus pelamis (L). Journal of Fish Disease 10:275-287.

Collette, B. B., J. R. McDowell, and J. E. Graves. 2006. Phylogeny of recent billfishes (Xiphioidei). Bulletin of Marine Science 79:455-468.

Cooke, S. J., and C. D. Suski. 2004. Are circle hooks an effective tool for conserving marine and freshwater recreational catch and release fisheries? Aquatic Conservation: Marine and Freshwater Ecosystems 14:299-326.

Cooke, S. J., C. D. Suski, B. L. Barthel, K. G. Ostrand, B. L. Tufts, and D. P. Phillip. 2003. Injury and mortality induced by four hook types on bluegill and pumpkinseed. North American Journal of Fisheries Management 23:883-893.

Cramer, J. 2000. Species reported caught in the U.S. commercial pelagic longline and gillnet fisheries from 1996-1998. U.S. National Marine Fisheries Service, Sustainable Fisheries Division, SFD-99/00-78 Southeast Fisheries Science Center, Miami Laboratory, Miami, Florida.

Ditton, R. B. 2002. A human dimensions perspective on catch-and-release fishing. Pages 19-28 in J. A. Lucy and A.L. Studholme, editors. Catch and release in marine recreational fisheries. American Fisheries Society, Symposium 30, Bethesda, Maryland.

Domeier, M. L., H. Dewar, and N. Nasby-Lucas. 2003. Mortality rate of striped marlin (Tetrapturus audax) caught with recreational tackle. Marine and Freshwater Research 54:435-445.

Goodyear, C. P. 2002. Factors affecting robust estimates of the catch and-release mortality using pop-off tag technology. Pages 172-179 in J. A. Lucy and A. L. Studholme, editors. Catch and release in marine recreational fisheries. American Fisheries Society, Symposium 30, Bethesda, Maryland.

Goodyear, C. P., and E. D. Prince. 2003. U.S. recreational 
harvest of white marlin. International Commission for the Conservation of Atlantic Tunas Collected Volume of Scientific Papers 55:624-632.

Graves, J. E., B. E. Luckhurst, and E. D. Prince. 2002. An evaluation of pop-up satellite tags for estimating postrelease survival of blue marlin (Makaira nigricans) from a recreational fishery. U.S. National Marine Fisheries Service Fishery Bulletin 100:134-142.

Grover, A. M., M. L. Palmer-Zwahlen, and M. S. Mohr. 2002. Hook-and-release mortality of Chinook salmon from drift mooching with circle hooks: management implications for California's ocean sport fishery. Pages 39-56 in J. A. Lucy and A.L. Studholme, editors. Catch and release in marine recreational fisheries. American Fisheries Society, Symposium 30, Bethesda, Maryland.

Hoolihan, J. P. 2004. Horizontal and vertical movements of sailfish (Istiophorus platypterus) in the Arabian Gulf, determined by ultrasonic and pop-up satellite tagging. Marine Biology 146:1015-1029.

Horodysky, A. Z., and J. E. Graves. 2005. Application of popup satellite archival tag technology to estimate postrelease survival of white marlin (Tetrapturus albidus) caught on circle and straight-shank ("J") hooks in the western North Atlantic recreational fishery. U.S. National Marine Fisheries Service Fishery Bulletin 103:84-96.

Horodysky, A. Z., D. W. Kerstetter, R. J. Latour, and J. E. Graves. 2007. Habitat utilization and vertical movements of white marlin (Tetrapturus albidus) released from commercial and recreational fishing gears in the western North Atlantic Ocean: inferences from short-duration pop-up archival satellite tags (PSATs). Fisheries Oceanography 16:240-256.

ICCAT (International Commission for the Conservation of Atlantic Tunas). 2001. Report of the fourth ICCAT billfish workshop. ICCAT Collected Volume of Scientific Papers 53:1-22.

ICCAT (International Commission for the Conservation of Atlantic Tunas). 2003. Report of the 2002 ICCAT white marlin stock assessment meeting. ICCAT Collected Volume of Scientific Papers 55:350-452.

Jesien, R. V., A. M. Barse, S. Smyth, E. D. Prince, and J. E. Serafy. 2006. Characterization of the white marlin (Tetrapturus albidus) recreational fishery off Maryland and New Jersey. Bulletin of Marine Science 79:647-657.

Jolley, J. W., Jr. 1975. On the biology of Florida East Coast Atlantic sailfish (Istiophorus platypterus). Pages 81-88 in R. S. Shomura and F. Williams, editors. Proceedings of the international billfish symposium, Kailua-Kona, Hawaii, 9-12 August 1972, Part 2, Review and Contributed Papers. U.S. Department of Commerce, Washington, D.C.
Kerstetter, D. W., and J. E. Graves. 2006. Survival of white marlin (Tetrapturus albidus) released from commercial pelagic longline gear in the western North Atlantic. U.S. National Marine Fisheries Service Fishery Bulletin 104:434-444.

Kerstetter, D. W., J. J. Polovina, and J. E. Graves. 2004. Evidence of shark predation and scavenging of fishes equipped with pop-up satellite archival tags. U.S. National Marine Fisheries Service Fishery Bulletin 102:750-756.

Mather, F. J., III, H. L. Clark, and J. M. Mason, Jr. 1975. Synopsis of the biology of the white marlin Tetrapturus albidus Poey (1861). NOAA Technical Report NMFS SSRF-675:55-94.

Muoneke, M. I., and W. M. Childress. 1994. Hooking mortality: a review for recreational fisheries. Reviews in Fisheries Science 2:123-156.

NMFS (National Marine Fisheries Service). 2006. Atlantic highly migratory species; recreational Atlantic blue and white marlin landings limit; amendments to the Fishery Management Plan for Atlantic Tunas, Swordfish, and Sharks and the Fishery Management Plan for Atlantic Billfish; final rule. Federal Register 71:190(2 October 2006):58058-58169.

Prince, E. D., M. Ortiz, and A. Venizelos. 2002. A comparison of circle hook and " $\mathrm{J}$ " hook performance in recreational catch-and-release fisheries for billfish. Pages 66-79 in J. A. Lucy and A. L. Studholme, editors. Catch and release in marine recreational fisheries. American Fisheries Society, Symposium 30, Bethesda, Maryland.

Prince, E. D., D. Snodgrass, E. Orbesen, J. P. Hoolihan, J. E. Serafy, and J. E. Schratweiser. 2007. Circle hooks, 'J' hooks and drop-back time: a hook performance study of the south Florida recreational live-bait fishery for sailfish, Istiophorus platypterus. Fisheries Management and Ecology 14:173-182.

Skomal, G. B., B. C. Chase, and E. D. Prince. 2002. A comparison of circle hook and straight hook performance in recreational fisheries for juvenile Atlantic bluefin tuna. Pages 57-65 in J. A. Lucy and A. L. Studholme, editors. Catch and release in marine recreational fisheries. American Fisheries Society, Symposium 30, Bethesda, Maryland.

White Marlin Status Review Team. 2002. Atlantic white marlin status review document. Report to National Marine Fisheries Service [NMFS], Southeast Regional Office, September 3, 2002. NMFS, St. Petersburg, Florida.

Wood, C. M., J. D. Turner, and M. S. Graham. 1983. Why do fish die after severe exercise? Journal of Fish Biology 22:189-201. 